\title{
Construir la casa
}

\begin{abstract}
Ángela Bonadies
angelabonadies@yahoo.com

"...los tiempos son nuevos pero la casa es inhabitable. No se ha levantado la mesa después de la comida; se han dejado en desorden los restos de un banquete cuyos comensales ya están lejos: salsas coaguladas, huesos, manchas de vino, migas; y, en desorden, los utensilios sucios." Le Corbusier en Cuando las catedrales eran blancas. Editorial Apóstrofe, 1999
\end{abstract}

La cita que abre este artículo la escribió Le Corbusier hace 70 años, exactamente en septiembre de 1934. Aunque a lo que se refería ha sufrido un descalabro histórico, el fondo de su comentario aún está vigente, aún sacude al que lo lee: la casa no es habitable porque olvidamos recoger la mesa, la mesa está llena de desechos, sucia, la habitación apesta, el tiempo nos encontró desprevenidos. Le Corbusier, en este caso, se refería a su utopía de las grandes ciudades verticales, a la construcción de catedrales modernas, de rascacielos, de edificaciones racionales útiles para la gente. Era un hombre de fe y un entusiasta. Hablaba de dejar atrás culturalmente tiempos pasados y prepararnos para esta modernidad que toca el cielo. Pero, paradójicamente, esa gran modernidad a la que se refería -representada por la construcción de grandes torres y un espíritu nuevo- ha sufrido una fractura más que evidente. Muchos pusieron de su parte para levantar, con espíritu masón, un nuevo concepto de vida y de casa, pero olvidaron que sobre la mesa se acumulaban alimentos fermentados. Aludiendo a sus palabras, reinsertándolas y reinterpretándolas en nuestro tiempo, la casa se construyó, finalmente, sobre bases carcomidas y desequilibradas, se ha ladeado, proyecta una brutal sombra sobre un lado, el más cercano al suelo, mientras el otro lado sufre de insolación permanente o de perturbaciones lunares. Como en la casa de Buster Keaton en One week, la casa del mundo se deconstruye, no por las pericias formales de un arquitecto conceptual, sino sometida a la fuerza centrípeta de un brutal vendaval que evidencia su vulnerabilidad, para terminar destrozada por un tren que la atraviesa. Sabiamente Keaton y su esposa deciden poner en venta los restos de la casa. Luego aparece sobre la pantalla el inevitable The end. Pero ¿a dónde van?

Probablemente esa fue la pregunta común de una serie de películas que se proyectaron en esta edición número 52 del festival de cine de San Sebastián. Después del vendaval ¿a dónde vamos? ¿Dónde construimos nuestra casa?

\section{La gran comilona: la casa del exceso}

"Cada cual procura, sin que nadie se lo haya indicado, mantener su tempo. En cualquier situación. En acontecimientos, emociones, aventuras, de la misma manera 
que en temporadas frías, lugares tórridos, le hace falta mantener igualada su temperatura.

(...)

Basta con tocar ligeramente un punto concreto del hipotálamo para que se acelere espectacularmente el tempo de un individuo que, sin predisposición alguna, por la aceleración incontrolable del pensamiento, de las impresiones, de las imágenes, de la palabra y de muchas funciones mentales, se pondrá como loco, presentará todos los síntomas de la psicosis maníaca.

Ciertos miedos, preocupaciones prolongadas, cambios hormonales pueden también provocar este cambio."

Henri Michaux en Escritos sobre pintura. Edita: Colegio Oficial de Aparejadores y Arquitectos Técnicos de Murcia, 2000. Colección de Arquilectura 40. Traducción de Chantal Maillard.

Aunque la cita de Michaux se refiere al momento en que realizó, bajo los efectos de la mezcalina y el ácido lisérgico, una serie de dibujos, puede también aplicarse perfectamente ese cambio de tempo a los personajes de La gran comilona de Marco Ferreri, esa película que en 1972 creó un acerado rechazo entre el público por su mal gusto y que destacó entre las proyectadas en una de las secciones especiales del festival: Incorrectos.

Cuatro amigos deciden reunirse varios días en la casa de uno de ellos, el abogado. La misión, nunca sabremos si es premeditada o simplemente deviene por inercia, se centrará en comer hasta reventar, follar hasta morir y todas las consecuencias previas al reventón y a la muerte que esta aceleración conlleva: cagarse, tirarse peos, marearse, aturdirse, vomitar y seguir comiendo y follando hasta morir de un placer que convierte a sus amos en esclavos. La casa es atravesada por una terca velocidad imposible de asir, por un cambio hacia más en los parámetros de comportamiento: una pequeña sociedad que decide tragar el superávit, ingurgitar los gigantes y excesivos flecos de la vida, pero, como bien escribió Sergi Sánchez en el catálogo del ciclo, sin hacer ninguna crítica a la sociedad de consumo. Sánchez cuenta que "La gran comilona surge de una grave crisis de diabetes que le ingresó (a Ferreri) en una clínica suiza. Allí empezó a obsesionarse con la muerte. Por aquel entonces nadie quería invertir ni un franco en sus películas..."

La casa de La gran comilona es arrasada por la muerte, por un exceso solidario e irreverente que desmitifica los grandes placeres para convertirlos en simples y absolutas respuestas fisiológicas, para igualar con un cuchillo de cocina lo humano y lo divino, para firmar sobre una tarta, incluso sin convicción, la sentencia de muerte de los dioses. Únicamente sobrevive la inmensa e inagotable maestra, invitada a posteriori al festejo, que deviene en ninfa-ninfómana-gulosa y que, tras una avalancha mortífera, deja en el jardín un paisaje de cadáveres de animales, porque los humanos, contradictoriamente, llenan el congelador. En esta naturaleza medio muerta y medio viva del jardín reposan los manjares que no se podrán comer, el exceso dentro del exceso, la gota que, después de rebasado el vaso, no moja sino empapa.

La multiplicación de los panes y los peces, de las carnes y la carne, de los postres y las mezclas se une en la película con los suplicios mitológicos: no es el suplicio de Tántalo que no alcanza los frutos del árbol, es el suplicio de quien alcanza un árbol que no para de producir y del que no puede dejar de tragar cuanto produce, porque sabe que, una vez acabada la jornada, empezará otra, y que la 
aceleración, el cambio de tempo, sólo hará que el instante que es la vida dure menos. En fin, tampoco es tan oscura la película. Al final la maestra "de ceremonia" deja los animales del carnicero en el jardín, los de Dios en el congelador y cierra la puerta. Pero ¿a dónde irá?

\section{Bombón el perro: buscando la casa}

"En algún momento las películas tienen que dejar de ser películas, de ser historias, para empezar a estar vivas y hacer que nos preguntemos qué tienen que ver con nosotros y con nuestras vidas...

....al plantear las cosas tan sencillamente, también intentamos que cualquiera dijera: muchas cosas serían posibles. No creo que la gente sea invariable. Forma parte de la estructura de la película que digamos "sí, las cosas irían mejor si fueran un poco diferentes". Y si seguimos dándole vueltas, van cada vez un poco mejor."

Rainer Werner Fassbinder en La anarquía de la imaginación. Editorial Paidós, Barcelona-Buenos Aires, 2002. Colección La memoria del cine 15. Traducción R.S. Carbó

Se puede decir que Bombón el Perro es otra "historia mínima" del cineasta argentino Carlos Sorín: es un relato tejido con una admirable sencillez, que se deja llevar por la contingencia y que logra en los espectadores lo que sugiere Fassbinder sobre estas líneas, cuando se refería a su película Todos nos llamamos Alí. Durante la proyección de Bombón todos estamos esperando que al protagonista, Juan Villegas, un hombre de 52 años que perdió su trabajo en una gasolinera, lo tracaleen, lo timen, le quiten lo poco que tiene. Pero al contrario, el personaje que deviene en persona o al revés -gracias a la forma de instalarse entre los espectadores- parte de lo "mínimo", por lo que no puede sufrir ninguna merma, y recorre los obstáculos con una naturalidad tal que nos obliga, amistosamente, a sospechar de nosotros mismos, es decir, a lograr ese intercambio que pocos logran y al que aludía el director alemán, a trasmutarnos en el otro, a ponernos en su pellejo y darnos cuenta que la historia ya no está en la pantalla, sino a la vuelta de una esquina contigua.

En una entrevista que me concedió Sorín el año 2002, en la presentación en San Sebastián de su anterior película, Historias Mínimas, comentó: "nosotros en Argentina tenemos una fuerte tradición de cine muy didáctico, por las dudas que no se entienda. Y yo procuré cortar con eso. Si se entiende se entiende y si no, queda la posibilidad de una mirada ambigua, más ambivalente. El espectador se vuelve más activo. El cine didáctico es terrible, terminas escuchándolo. Un silencio, una pausa dentro de la película, de repente tiene una fuerza que desde el guión es imposible de evaluar. Yo hice la experiencia de terminar con los actores, ahora la próxima es terminar con los guionistas. Y la tercera etapa de este dogma es terminar con los productores." La última etapa, sin duda, resultará ser la más difícil, por el entramado del mercado cinematográfico, y probablemente la menos necesaria si Sorín se mantiene en ese borde delicado y agudo de documentar la ficción y ficcionar la realidad en el que, como él mismo dice en el catálogo de presentación de la película, "ni los personajes ni las situaciones son enteramente ficticias, ni las semejanzas fueron una mera coincidencia".

Juan Villegas, el no-actor principal de la película, se queda sin trabajo, ese es su punto de partida. En una casi absoluta precariedad intenta vivir de vender cuchillos tallados que él fabrica; pero no vende. Va de aquí para allá por el eterno horizonte de la Patagonia y, gracias a un encuentro en medio de las largas rutas, su vida da un vuelco. Le regalan un perro, pero no cualquiera sino un dogo argentino, el 
famoso Bombón que da nombre a la película. En secuencias cargadas de sentido del humor (hay que decir que fueron pocas las cintas que nos dieron ese alegre respiro en este festival) el perro le otorga al bueno de Juan otro estatus, suficientemente alto como para, por ejemplo, ser atendido de manera especial por el director de un banco, del banco donde cobra su insustancial liquidación. La dureza que subyace en la película se susurra sin pesadez pedagógica y sin elocuentes diálogos demagógicos y dramáticos, al contrario, se percibe como detalle entre los gestos, en una mirada de reojo, en alguien que se queda callado, en una respuesta parca o en el comentario descriptivo, sin más, como "me gané una lata de aceite y unos anteojos negros... de esos que salen en televisión". En pocas palabras, Juan sigue sin blanca pero tiene unos anteojos negros como negro es su futuro, da la impresión que nos dice irónicamente el director, con una sonrisa ladeada. Pero Juan sigue buscando su casa y a través del perro y una cantante no-árabe de música árabe que conoce en un restaurante libanés, parece vislumbrarla.

Pero sigue en la ruta ¿hacia dónde va?

\section{Iván Z.: la casa del cine}

"...cuando ahora veo cortometrajes de alumnos que salen de la escuela, y que están fascinados por la técnica, por la factura, las grúas y los travellings, me gustaría reivindicar la belleza tosca de La boulangère de Monceau que tiene también que ver con la tosquedad de Jean Vigo en L'atalante, jviva la tosquedad!" José Luis Guerín en conversación con Álvaro Arroba en Letras de Cine. Número extra monográficos, Valladolid, 2004

Andrés Duque ha estado siguiendo la pista de Iván Zulueta desde que vio en la Cinemateca Nacional de Caracas la película Arrebato(1979) y se convirtió en uno de sus asiduos cultores. Al mudarse a España, Duque buscó todo lo relacionado con Zulueta y encontró más la leyenda de un personaje mítico, huraño, encerrado en una especie de palacio atemporal, que el relato de una persona real, de un artista. Desde ese instante se plantó en la idea de llenar un vacío y hacer un documental sobre el cineasta. Contactó con él a través de un amigo común y se puso en marcha: primero consolidó una profunda relación de amistad y después emprendió el trabajo. Por esta razón la casa que construyó Duque en su documental Iván $Z$. tiene fuertes amarres a tierra, está cimentada sobre bases estables que presentan imágenes que, más que bellas, son justas y necesarias, parafraseando a Guerín cuando habla sobre la ética de Rossellini.

En Iván Z. Andrés Duque construye, con medios sencillos y una absoluta honestidad, la casa de Zulueta y a la vez la casa del cine. La estructura arquitectónica de la película comienza afuera, con la hermosa enredadera que cubre la casa, y llega al ático o planta superior donde Iván Z. despliega sus recuerdos y joyas de cromos y comics, que Duque evoca como el encuentro con los objetos de la infancia y sus vampirizantes y eróticos placeres. La enredadera, que es apertura y cierre de la obra, también funciona como metáfora del encierro, de una dulce decadencia, de una vida apartada. Como en Bugambilia (1944) del Indio Fernández, la casa es para Zulueta la ventana desde la cual se mira, de la que se aleja y a la que vuelve para convertirla en un mundo dentro del cual se habita.

Junto a las imágenes que filmó durante tres días de trabajo continuo -entre las cuales resalta la de la aparición sorpresiva de la madre de Iván- Duque intercaló en el montaje trozos de cintas de Zulueta, lo que recrea al cine dentro del cine y ayuda a construir el documental también como ficción que fluye 
y se entrelaza con lo real. Incluso logra reproducir una imagen casi idéntica de Zulueta -que nos permite viajar en el túnel del tiempo- en la que éste está de pie frente al ventanal de su casa, en una cinta en blanco y negro de los setenta. Luego lo vemos en la actualidad, desde el mismo ángulo, a color, captado por la cámara de Andrés Duque, único técnico de este documental en el que sólo hubo colaboraciones importantes durante la post producción.

Frente a los planos que intercala de Arrebato, la cámara en mano de Duque, sus encuadres rápidos, el movimiento y su uso tosco del zoom hablan de su postura en y ante el cine, dando una pequeña lección de la diferencia entre plano y contraplano, como bien explicó Godard en una escena impresionante de Notre Musique. Por su parte Zulueta sólo se animó a tomar la cámara una vez e hizo un hermoso travelling ascendente de la enredadera, como una referencia poética de este contemporáneo Thomas De Quincey del caballo que en la película sentencia: "ocuparse es un coñazo".

Detrás de la enredadera Iván Zulueta reconstruye su cine y su casa en Iván Z. Pero cabe la pregunta ¿volverá a habitar la casa del cine?

\title{
4. Nuestra Música: la casa de la guerra
}

\begin{abstract}
"desmembrado y hecho trizas, como tu propio relato alcanzas al fin el don de la ubicuidad te dispersas de país en país de ciudad en ciudad de barrio en barrio: estás a la vez en los disturbios saqueos enfrentamientos de Brixton y Notting Hill junto a hindús y paquistaneses insurrectos: en el devastado fantasmal South Bronx de Young Lords y Black Panthers con boricuas y africanos drogados: en el Kreuzberg turcoberlinés y su onírico paisaje de inmuebles abiertos al vacío y sombras fugitivas de apariencia sonámbula: la metrópolis futura la encuentras aquí: ruinas vestigios escombros de una próspera civilización arrasada: portal ennegrecido de difunta estación vías de ferrocarril invadidas por la maleza bosques improvisados sobre viejas arterias espacios verdes borrándolo todo: macizas embajadas de aspecto selvático bunkers tapizados de hiedra rieles de tranvía perdidos en la arena viejo puerto fluvial transformado en jardín" Juan Goytisolo en Paisajes después de la batalla. Editorial Montesinos, Barcelona, 1984
\end{abstract}

De Nuestra Música de Jean-Luc Godard poco me atrevo a decir, más que la guerra una y otra vez, la ubicuidad dura y estéril de la guerra. Como en el fragmento de Juan Goytisolo, la casa ha sido devastada y sólo queda edificar ruinas, instalarnos en babélicas trincheras desde las cuales defendernos de la tosca mano del imperio, cualquiera que sea, cualquiera que tome el relevo. Este fragmento podría ser la vuelta de guante de la esperanza moderna de Le Corbusier que abre el artículo: explosiones, campos destruidos, derrumbamientos humanos, desplazamientos, ejecuciones como en el Infierno de Nuestra Música; bibliotecas enteras barridas como un auto da fe del mercado bélico, letras muertas, la importancia de escuchar al otro, la del otro de hablar, la urgencia de la poesía y el arte en el Purgatorio de Nuestra Música; para terminar en el Paraíso, irónicamente custodiado por idílicos marines estadounidenses. En la película queda al descubierto el absurdo, como la joven que se sacrifica con una cartera llena de libros "por Palestina y porque vivo en Tel Aviv. Deseo ver un lugar en el que parece posible una reconciliación". Queda al descubierto la poesía en la 
secuencia en que Juan Goytisolo habla en la devastada biblioteca o en las calles de Sarajevo: la luz es el primer animal visible de lo invisible; quien mata a una persona por defender una idea, mata a una persona, no defiende una idea.

Godard así lo presenta:

"He aquí las músicas el resto es impostura

He aquí el contra plano el resto es procedimiento

Y hacia el paraíso he aquí la culminación

Y he aquí nuestro amor y nuestro entendimiento"

Nuestra Música recrea el lado en sombra de nuestra casa ladeada, el lado que sufre la claustrofóbica existencia de horizontes estallados, del suelo árido y fisurado, de la memoria borrada. Porque la casa del otro está arrasada, pero "hay más inspiración y riqueza humana en la derrota que en la victoria".

\section{Apuntes:}

Bombón el perro de Carlos Sorín fue proyectada en la Sección Oficial del 52 Festival Internacional de Cine de San Sebastián, en la que ganó el premio Fipresci.

Iván Z. de Andrés Duque fue proyectada en la sección especial Incorrectos junto a Arrebato (1979) de Iván Zulueta.

Nuestra Música de Jean-Luc Godard fue proyectada en la sección Zabaltegui: Perlas de otros Festivales. Obtuvo el Gran Premio Fipresci a la mejor película de 2004.

\section{Formato de citación}

Bonadies, Á. (2004). Construir la casa. Athenea Digital, 6. Disponible en http://antalya.uab.es/athenea/num6/bonadies.pdf

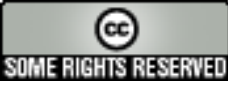

Este texto está protegido por una licencia Creative Commons.

Usted es libre de copiar, distribuir, exhibir y comunicar la obra bajo las siguientes condiciones:

Reconocimiento: Vd. debe reconocer y dar crédito al autor original.

NoComercial. Vd. no puede utilizar esta obra para fines comerciales.

NoDerivados. Vd. no puede alterar, transformar, o añadir nada a esta obra.

\section{Resumen de licencia}

Texto completo de la licencia 